\title{
Pengembangan Perangkat Pembelajaran Berbasis Penemuan Terbimbing Menggunakan Hypercontent untuk Meningkatkan Kemampuan Berpikir Kritis Matematis Siswa
}

\author{
Maulidia Wanahari ${ }^{1}$, Zul Amry ${ }^{2}$, Elmanani Simamora ${ }^{3}$ \\ 1,2,3 Prodi Pendidikan Matematika Pascasarjana, Universitas Negeri Medan \\ Universitas Negeri Medan, Jalan William IskandarPasar V, Medan, Indonesia \\ maulidiawanahari123@gmail.com
}

\begin{abstract}
Online learning (in the network) is learning online through specified media. This study aims to: 1) describe how the level of validity, practicality and effectiveness of guided discovery-based learning tools using Hypercontent to improve critical mathematical thinking skills at SMAN 1 Tambangan; 2) describe the improvement of students' mathematical critical thinking skills using guided discovery-based learning tools using Hypercontent at SMAN 1 Tambangan The method used in this research is development research. The subjects in this study were 11th grade students of SMAN 1 Tambangan in the 2021/2022 academic year. The results showed that 1) Guided discovery-based learning tools using hypercontent to improve students' mathematical critical thinking skills that were developed already met the criteria of being valid, practical and effective; 2) The improvement of mathematical critical thinking skills using guided discovery-based learning tools using hypercontent that has been developed seen from the $\mathrm{N}$-gain value in the first trial of 0.33 increased to 0.4 in the second trial, meaning that it is in the "medium" category.
\end{abstract}

Keywords: Online Learning, Guided Discovery, Hypercontent, Critical Thinking Ability

\begin{abstract}
Abstrak
Pembelajaran Daring (dalam jaringan) merupakan belajar secara online melalui media-media yang ditentukan. Penelitian ini bertujuan Untuk : 1) mendeskripsikan bagaimana tingkat Validitas, kepraktisan dan efektifitas perangkat pembelajaran berbasis penemuan terbimbing menggunakan Hypercontent untuk meningkatkan kemampuan berpikir matematis kritis di SMAN 1 Tambangan; 2) mendeskripsikan Peningkatan kemampuan berpikir kritis matematis siswa dengan menggunakan perangkat pembelajaran berbasis penemuan terbimbing menggunakan Hypercontent di SMAN 1 Tambangan. Penelitian ini menggunakan model pengembangan 4-D oleh Sivasailam Thiagarajan, Dorothy S. Semmel, dan Melvyn I. Semmel (1974). Model ini terdiri dari 4 tahap pengembangan yaitu Define (Pendefinisian), Design (Perancangan), Develop (Pengembangan) dan Disseminate (Penyebaran). Subjek dalam penelitian ini adalah siswa kelas XI SMAN 1 Tambangan tahun Ajaran 2021/2022. Hasil penelitian menunjukkan bahwa 1) Perangkat pembelajaran berbasis penemuan terbimbing menggunakan hypercontent untuk meningkatkan kemampuan berpikir kritis matematis siswa yang dikembangkan sudah memenuhi kriteria valid, praktis dan efektif; 2) Peningkatan kemampuan berpikir kritis matematis menggunakan perangkat pembelajaran berbasis penemuan terbimbing menggunakan hypercontent yang telah dikembangkan dilihat dari nilai $N$-gain pada uji coba I sebesar 0,33 meningkat menjadi 0,4 pada uji coba II, artinya berada dalam kategori "sedang".
\end{abstract}

Kata kunci: Pembelajaran Daring, Penemuan Terbimbing, Hypercontent, Kemampuan Berpikir Kritis

Copyright (c) 2022 Maulidia Wanahari, Zul Amry, Elmanani Simamora

$\triangle$ Corresponding author: Maulidia Wanahari

Email Address maulidiawanahari123@gmail.com (Jalan William IskandarPasar V, Medan, Indonesia)

Received 23 December 2021, Accepted 05 February 2022, Published 06 February 2022

\section{PENDAHULUAN}

Pada saat ini Indonesia dihadapkan pada tantangan besar akibat dari pandemi covid-19 yang sedang terjadi di Indonesia. Banyak korban yang dirugikan dari pandemi covid-19 ini salah satunya lembaga pendidikan, dimana untuk menangani dan mencegah penyebaran virus covid-19 yang semakin menyebar luas, maka salah satu upaya pencegahan sebaran covid-19 yang dilakukan 
Pengembangan Perangkat Pembelajaran Berbasis Penemuan Terbimbing Menggunakan Hypercontent untuk Meningkatkan Kemampuan Berpikir Kritis Matematis Siswa, Maulidia Wanahari ${ }^{1}$, Zul Amry ${ }^{2}$, Elmanani Simamora 669

Kementrian pendidikan dan Kebudayaan terhadap lembaga pendidikan, yaitu dengan kebijakan belajar dari rumah, melalui pembelajaran daring.

Pemberlakuan kebijakan social distancing, physical distancing, menjadi dasar kebijakan pendidikan dengan belajar dari rumah menggunakan dan memanfaatan internet berlaku secara serentak. Kebijakannya yang dilakukan pemerintah seperti isolasi, social and physical distancing hingga pembatasan sosial berskala besar (PSBB) ini mengharuskan semua warga untuk tetap stay at home, bekerja, beribadah dan belajar di rumah. Kondisi demikian menuntut lembaga pendidikan untuk melakukan inovasi dalam proses pembelajaran. Salah satu bentuk inovasi tersebut ialah dengan melakukan pembelajaran secara online atau daring (dalam jaringan). Pembelajaran daring memang memberikan media pembelajaran yang variatif seperti media video pembelajaran yang terhubung ke youtube, media video conference, media jurnal ilmiah atau topik yang tersistem secara digital. Tetapi kemajuan teknologi pembelajaran harus didukung dengan sarana dan prasarana yang memadai, seperti meratanya jaringan internet ke sekolah-sekolah yang ada di pedesaan.

Dalam menyikapi surat edaran dari pemerintah, pihak sekolah harus menyediakan media dan sumber belajar pembelajaran jarak jauh daring. Untuk itu pihak sekolah menghimbau kepada seluruh peserta didik menggunakan smartphone (gadget) maupun laptop pada pelaksanaan belajar dari rumah. Penggunaan teknologi informasi (TI) dalam pembelajaran dianggap alternatif dalam menyikapi kondisi khusus dan membawa perubahan tradisi atau budaya pembelajaran serta menjadi sistem pembelajaran mandiri. Model pembelajaran yang berhubungan dengan TI dan kini menjadi perhatian dunia pendidikan adalah model pembelajaran berbasis komputer dan pembelajaran melalui media elektonik berbasis web base learning (Wena, 2009).

Pada pembelajaran berbasis komputer peserta didik akan berinteraksi dan berhadapan secara langsung dengan komputer secara individual (Wena, 2009). Pembelajaran yang biasanya guru dan peserta didik yang selalu berada di satu tempat maka dengan adanya penggunaan tekonologi pembelajaran dapat dilakukan dengan menggunakan media yang sudah dirancang dengan baik yang merupakan pembelajaran jarak jauh.

Perkembangan teknologi yang semakin maju, tentunya berpengaruh kedalam berbagai sektor kehidupan manusia. Perkembangan ini turut berperan dalam perkembangan sebuah perangkat pembelajaran. Media pembelajaran menjadi semakin menarik dan semakin ringkas, salah satu perkembangan perangkat pembelajaran yang saat ini banyak digunakan adalah media pembelajaran yang memadukan teknologi ke dalam dunia pendidikan, seperti modul pembelajaran interaktif dengan menggunakan komputer/laptop, jaringan komputer, animasi 2D, 3D, Quick Response Code (QRCode) dan lain-lain. Menurut Siang, Ibrahim, \& Rusmono (Siang, Ibrahim, and Rusmono, 2017) modul merupakan media yang bisa menghantarkan pesan kepada siswa. Oleh karena itu penelitian ini bertujuan untuk mengatasi berbagai permasalahan yang telah diuraikan diatas dengan mengembangkan perangkat pembelajaran menggunakan hypercontent. 
Adapun makna hypercontent menurut Prawiradilaga \& Chaeruman (Prawiradilaga, D. S., \& Chaeruman, 2018), yaitu "hypercontent" diadopsi dari pola membaca digital yang bersifat nonlinear. Makna lain dari hypercontent ini adalah linked (tertaut) dan virtual world (dunia maya). Secara sederhana hypercontent dapat dipahami sebagai konsep yang menjalinkan satu materi dan materi lain secara simultan dalam satu program teknologi digital tertentu (Prawiradilaga, Widyaningrum, and Ariani, 2017).

Proses pembelajaran dengan Kurikulum 2013 membutuhkan keterlibatan siswa dalam proses pembelajaran dan berpusat pada siswa. Namun, berdasarkan pengamatan yang dilakukan peneliti siswa kelas XI SMAN 1 Tambangan masih pasif dalam proses pembelajaran dan bergantung pada informasi yang diberikan oleh guru, di era new normal ini diharapkan hypercontent sebagai alat bantu pada penelitian ini dapat membuat siswa lebih kritis dalam berpikir walaupun belajar dilakukan dari rumah dan secara online akan tetapi tidak membatasi siswa jadi lebih pasif tetapi lebih aktif dan mandiri untuk mencari tau sendiri materi yang akan dipelajari melalui video pembelajaran yang ada pada QR Code yang diberikan sesuai dengan kompetensi pembelajaran yang akan dipelajari.

Selanjutnya hasil wawancara penulis dengan guru matematika di SMAN 1 Tambangan yaitu Juliani Hasibuan, S.Pd. pada tanggal 11 Januari 2021 terungkap fakta bahwa ada beberapa permasalahan yang dijumpai dalam pembelajaran matematika, diantaranya: siswa bersikap pasif dalam menerima pelajaran dilihat dari laporan pembelajaran daring. Berdasarkan analisis yang peneliti lakukan terhadap perangkat yang digunakan di SMAN 1 Tambangan, terdapat beberapa kelemahan pada perangkat pembelajaran. Mulai dari RPP yang disusun oleh guru yang dipakai sebagai rencana pembelajaran, tidak pernah divalidasi oleh pakar, sehingga terlihat bahwa guru kurang memberi perhatian untuk dapat meningkatkan kualitas pembelajaran yang dimiliki siswa.

Sebagai tanggapan terhadap permasalahan yang timbul dalam pembelajaran matematika seperti yang telah diuraikan di atas, maka perlu bagi guru untuk memilih pembelajaran yang dapat memperbaiki kualitas pembelajaran matematika, salah satunya dengan memilih metode dan model pembelajaran yang digunakan pada proses pembelajaran yang lebih mengaktifkan siswa, model pembelajaran yang efektif dan baik untuk digunakan dalam proses pembelajaran matematika. Namun, jika ingin mengembangkan pembelajaran matematika yang mengaktifkan siswa pada saat pandemi covid 19 ini, salah satu model pembelajaran yang dapat digunakan adalah model penemuan terbimbing dimana model ini bisa membuat siswa lebih aktif dalam pembelajaran secara mandiri walaupun harus belajar dari rumah (Mardati, 2018).

Peran siswa cukup besar dalam pembelajaran dengan metode penemuan terbimbing karena pembelajaran tidak lagi terpusat pada guru tetapi pada siswa. Guru memulai kegiatan belajar mengajar dengan menjelaskan kegiatan yang akan dilakukan siswa dan mengorganisir kelas untuk kegiatan seperti pemecahan masalah, investigasi atau aktivitas lainnya. Pemecahan masalah merupakan suatu tahap yang penting dan menentukan. Ini dapat dilakukan secara individu maupun kelompok. Dengan membiasakan siswa dalam kegiatan pemecahan masalah dapat diharapkan meningkatkan kemampuan 
Pengembangan Perangkat Pembelajaran Berbasis Penemuan Terbimbing Menggunakan Hypercontent untuk Meningkatkan Kemampuan Berpikir Kritis Matematis Siswa, Maulidia Wanahari ${ }^{1}$, Zul Amry ${ }^{2}$, Elmanani Simamora 671

siswa dalam mengerjakan soal matematika, karena siswa dilibatkan dalam berpikir matematika pada saat manipulasi, eksperimen, dan menyelesaikan masalah. Sedangkan peranan guru dalam pembelajaran dengan metode penemuan terbimbing adalah menyatakan persoalan, kemudian membimbing siswa untuk menemukan penyelesaian dari persoalan itu dengan perintah-perintah atau dengan pertanyaanpertanyaan.

Menurut Bruner belajar penemuan merupakan pencarian pengetahuan secara aktif oleh individu dan dengan sendirinya memberikan hasil yang lebih baik. Sedangkan Lefrancosis menyatakan bahwa belajar penemuan sebagai suatu pembelajaran yang mana siswa tidak disuguhi materi dalam bentuk akhir tetapi lebih diutamakan agar siswa mengorganisir dalam diri mereka (Siahaan, 2017)

Dari beberapa perspektif sebelumnya pendekatan yang dipilih hendaknya disesuaikan dengan metode, media dan sumber belajar lainnya yang relevan dalam menyampaikan informasi dan membimbing siswa agar terlibat secara optimal, sehingga siswa dapat memperoleh pengalaman belajar dalam rangka menumbuh kembangkan kemampuan kognitif, afektif dan psikomotornya. Salah satu model pembelajaran yang memfokuskan pembelajaran pada siswa adalah penemuan terbimbing.

Dalam pendekatan penemuan terbimbing, guru harus memberikan kesempatan siswanya untuk menjadi seorang problem solver, seorang saintis, dan ahli matematika. Kemudian dapat membangun kepercayaan diri, minat dan ketertarikan siswa kepada matematika, sehingga dengan menerapkan pendekatan penemuan terbimbing dalam pembelajaran diharapkan dapat membuat siswa semakin menyukai matematika.

\section{METODE}

Penelitian ini termasuk penelitian pengembangan (development research). Penelitian ini menggunakan model pengembangan 4-D oleh Sivasailam Thiagarajan, Dorothy S. Semmel, dan Melvyn I. Semmel. Model ini terdiri dari 4 tahap pengembangan yaitu Define (Pendefinisian), Design (Perancangan), Develop (Pengembangan) dan Disseminate (Penyebaran).

Penelitian ini dilaksanakan di SMAN 1 Tambangan yang merupakan salah satu sekolah menengah atas di kecamatan Tambangan, Kabupaten Mandailing Natal pada semester ganjil tahun Ajaran 2021/2022. Subjek dalam penelitian ini adalah siswa kelas XI SMAN 1 Tambangan tahun Ajaran 2021/2022, sedangkan objek penelitian ini adalah perangkat pembelajaran yang dikembangkan berdasarkan model penemuan terbimbing pada materi barisan dan deret.

Metode penelitian dan pengembangan (Research and Development) merupakan metode penelitian yang digunakan untuk menghasilkan produk tertentu dan menguji keefektifan produk tersebut. (Sugiyono, 2012) Desain penelitian yang digunakan dalam penelitian ini adalah desain penelitian pengembangan model 4-D (Four D Models) menurut Thiagarajani. Hal ini meliputi 4 tahap yaitu tahap pendefinisian (define), perancangan (design), pengembangan (develop) dan penyebaran 
(disseminate). Akan tetapi tahap penyebaran tidak dilakukan, sehingga tahap keempat ini tidak dijelaskan secara mendalam.

Perangkat pembelajaran yang telah divalidasi diujicobakan ke kelas uji coba I. setelah selesai ujicoba I, diberikan tes kemampuan berpikir kritis matematis. Hasil uji coba I dijadikan acuan revisi perangkat pembelajaran sehingga dihasilkan draf III untuk uji coba II. Setelah selesai uji coba II, diberikan diberikan tes kemampuan berpikir kritis untuk melihat peningkatannya. Selanjutnya data hasil uji coba lapangan ini dianalisis dan kemudian direvisi sehingga pada akhirnya, diperoleh perangkat pembelajaran yang final.

Adapun rancangan uji coba penelitian ini menggunakan rancangan One Group PretestPostetst Design. Langkah pertama melakukan pengukuran sebagai ujicoba awal (pretest). Selanjutnya dikenakan perlakuan dalam jangka waktu tertentu, kemudian dilakukan uji akhir (post-test). Rancangan penelitian desain Pre-test and Post-test Group, dengan pola sebagai berikut: (Lestari, K.E dan Yudhanegara, 2017)

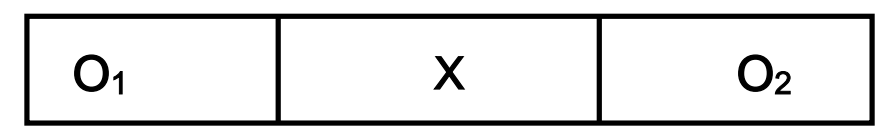

dengan:

$\mathrm{O}_{1}=\mathrm{Uji}$ awal (pre-test) dilakukan untuk mengetahui hasil belajar sebelum diberi perlakuan

$\mathrm{X}=$ Perlakuan melalui pembelajaran yang berbasis penemuan terbimbing menggunakan hypercontent yang telah dikembangkan. Selama perlakuan instrument yang dipakai adalah: Instrumen tes kemampuan berpikir kritis matematis siswa.

$\mathrm{O}_{2}=\mathrm{Uji}$ akhir (post-test) dilakukan untuk mengetahui hasil belajar produk, proses dan tes kinerja siswa setelah diberi perlakuan. Setelah post-test dilakukan maka diberi angket respon siswa terhadap pembelajaran.

Untuk menghitung peningkatan kemampuan berpikir kritis matematis setelah menggunakan pengembangan perangkat pembelajaran menggunakan pembelajaran penemuan terbimbing ditentukan dengan rumus gain. Menurut Hake (Yohanis, J., Triwiyono, Modouw, 2013) gain ternormalisasi dihitung dengan rumus berikut:

$$
N-\text { Gain }=\frac{S_{\text {post }}-S_{\text {pre }}}{S_{\text {max }}-S_{\text {pre }}}
$$

Keterangan : $N-$ Gain $=$ skor gain ternormalisasi

$S_{\text {post }} \quad=$ skor tes akhir

$S_{\text {pre }} \quad=$ skor tes awal

$S_{\max }=$ skor maksimum

Kategori gain ternormalisasi disajikan seperti pada Tabel 1. berikut: 
Pengembangan Perangkat Pembelajaran Berbasis Penemuan Terbimbing Menggunakan Hypercontent untuk Meningkatkan Kemampuan Berpikir Kritis Matematis Siswa, Maulidia Wanahari ${ }^{1}$, Zul Amry ${ }^{2}$, Elmanani Simamora 673

Tabel 1. Kategori gain ternormalisasi

\begin{tabular}{|c|c|}
\hline Skor $N$-Gain & Kriteria $N$-Gain \\
\hline $0,00<N-$ Gain $\leq 0,30$ & Rendah \\
\hline $0,30<N-$ Gain $\leq 0,70$ & Sedang \\
\hline$N-$ Gain $>0,70$ & Tinggi \\
\hline
\end{tabular}

Diadaptasi dari Hake (Yohanis, J., Triwiyono, Modouw, 2013)

\section{HASIL DAN DISKUSI}

\section{Tahap Pendefinisian (Define)}

Berdasarkan hasil observasi dan analisis terhadap perangkat pembelajaran di SMAN 1 Tambangan, menunjukkan bahwa selama ini guru belum memiliki perangkat pembelajaran yang dapat meningkatkan kemampuan berpikir kritis matematis. Rencana Pelaksanaan Pembelajaran (RPP) yang ada bukan merupakan gambaran dari proses pembelajaran yang dilaksanakan. LKPD yang ada digunakan tidak sesuai dengan RPP, sehingga tujuan pembelajaran yang diinginkan pada RPP tidak terdapat dalam LKPD dan buku pegangan yang digunakan tidak memadai untuk digunakan dimasa pandemi covid 19 ini. Selain itu, dalam proses pembelajaran siswa tidak dilibatkan dalam proses menemukan pengetahuannya melainkan langsung diberikan oleh guru. Hal ini diduga menjadi penyebab kemampuan berpikir kritis matematis siswa masih kurang baik.

Berdasarkan hasil observasi di SMAN 1 Tambangan pada tanggal 11 Januari 2021, RPP yang digunakan guru matematika disekolah SMAN 1 Tambangan tidak dirancang oleh guru itu sendiri melainkan copy-paste dari internet. RPP yang dibuat guru juga tidak menggunakan model, metode, sumber dan media yang dapat mengaktifkan siswa. RPP yang digunakan hanya memuat kegiatan yang dilakukan guru, sehingga dalam proses pembelajaran hanya menekankan kegiatan guru, sementara siswa hanya sebagai pendengar atau penerima pasif. Selain itu RPP yang digunakan tidak sesuai dengan kharakteristik siswa, situasi dan kondisi di SMAN 1 Tambangan. RPP tersebut juga tidak memuat tujuan pembelajaran yang dapat meningkatkan kemampuan berpikir kritis matematis siswa. Kemudian untuk lembar kegiatan yang digunakan siswa berisi soal - soal rutin dalam bentuk essay dan pilihan ganda. LKPD yang digunakan siswa SMAN 1 Tambangan tidak sesuai dengan RPP yang dimiliki oleh guru sehingga tujuan pembelajaran yang dirumuskan dalam RPP tidak terangkum dalam LKPD. Selain itu buku yang digunakan oleh siswa masih menggunakan buku biasa yang belum menggunakan materi yang simultan atau hypercontent yang bisa mengarahkan siswa belajar secara mandiri pada masa pandemi ini. Buku tersebut langsung memuat rumus yang harus digunakan dalam materi tersebut dilanjutkan dengan pemberian contoh soal yang terdapat dalam buku yang digunakan juga belum memuat soal penemuan terbimbing, soal yang digunakan berupa soal - soal rutin. Selain itu buku siswa tidak menuntun siswa untuk berpikir kritis dalam menyelesaikan masalah yang diberikan. Buku siswa yang diberikan juga belum memuat konsep yang benar. Oleh karena itu buku siswa yang digunakan siswa SMAN 1 Tambangan belum dapat meningkatkan kemampuan berpikir kritis matematis siswa. 


\section{Tahap Perancangan (Design)}

\section{Hasil Penyusunan Tes}

Dasar dari penyusunan tes adalah analisis tugas dan analisis konsep yang dijabarkan dalam spesifikasi tujuan pembelajaran. Tes yang dimaksud adalah tes kemampuan berpikir kritis matematis pada materi Barisan dan Deret.

\section{Hasil Pemilihan Media}

Media pembelajaran yang disusun meliputi: Rencana Pelaksanaan Pembelajaran (RPP), Lembar Kerja Peserta Didik, Modul, serta Tes Kemampuan Berpikir Kritis Matematis Siswa.

\section{Hasil Pemilihan Format}

Hasil pemilihan format dalam penelitian ini disesuaikan dengan kurikulum 2013. Komponen RPP terdiri atas: Identitas sekolah yaitu nama satuan pendidikan Identitas mata pelajaran atau tema/subtema; Kelas/semester; Materi pokok: Alokasi waktu ditentukan sesuai dengan keperluan untuk pencapaian KD dan beban belajar dengan mempertimbangkan jumlah jam pelajaran yang tersedia dalam silabus dan KD yang harus dicapai; Tujuan pembelajaran yang dirumuskan berdasarkan $\mathrm{KD}$, dengan menggunakan kata kerja operasional yang dapat diamati dan diukur, yang mencakup sikap, pengetahuan, dan keterampilan; Kompetensi dasar dan indikator pencapaian kompetensi; Materi pembelajaran, memuat fakta, konsep, prinsip, dan prosedur yang relevan, dan ditulis dalam bentuk butir-butir sesuai dengan rumusan indikator ketercapaian kompetensi; Metode pembelajaran, digunakan oleh peneliti adalah Penemuan Terbimbing dan KD yang akan dicapai; berupa alat bantu proses pembelajaran untuk menyampaikan materi pelajaran; Sumber belajar, dapat berupa buku, smartphone/gadget media cetak dan elektronik, alam sekitar, atau sumber belajar lain yang relevan; Langkah-langkah pembelajaran dilakukan melalui tahapan pendahuluan, inti, dan penutup; dan penilaian hasil pembelajaran.

Format untuk buku siswa atau modul disesuaikan dengan aturan Badan Standar Nasional Pendidikan (BSNP) yakni yang menjelaskan buku harus memenuhi kelayakan isi, kelayakan penyajian, kelayakan bahasa dan kelayakan kegrafikan. Format LKPD dibuat berwarna sehingga siswa akan tertarik dan termotivasi untuk belajar sedangkan untuk format tes kemampuan berpikir kritis matematis mengacu pada indikator kemampuan berpikir kritis matematis siswa. Keseluruhan perangkat pembelajaran disesuaikan dengan model pembelajaran penemuan terbimbing agar menjadi satu kesatuan untuk kemudian diharapkan penerapannya berdampak pada peningkatan kemampuan berpikir kritis matematis siswa SMAN 1 Tambangan.

\section{Hasil Perancangan Awal}

Pada tahap rancangan awal dihasilkan rencana pelaksanaan pembelajaran untuk dua kali pertemuan pada uji coba lapangan.

\section{Deskripsi Tahap Pengembangan (Develop)}

Sebelum perangkat digunakan dalam penelitin, perangkat harus divaladasi terlebih dahulu. Hasil validasi para ahli terhadap RPP, LKPD, Modul, dan Tes Kemampuan Berpikir Kritis Matematis 
Pengembangan Perangkat Pembelajaran Berbasis Penemuan Terbimbing Menggunakan Hypercontent untuk Meningkatkan Kemampuan Berpikir Kritis Matematis Siswa, Maulidia Wanahari ${ }^{1}$, Zul Amry ${ }^{2}$, Elmanani Simamora 675

memiliki kategori yaitu "valid", dimana kategori minimal perangkat pembelajaran adalah "valid". Sehingga perangkat pembelajaran tersebut dapat digunakan dengan revisi kecil sesuai dengan saran revisi yang diberikan para ahli.

Tabel 1. Rekapitulasi Hasil Validasi Perangkat Pembelajaran oleh Ahli

\begin{tabular}{|l|l|c|c|}
\hline No & \multicolumn{1}{|c|}{ Perangkat yang dinilai } & $\begin{array}{c}\text { Nilai rata-rata } \\
\text { total validasi }\end{array}$ & $\begin{array}{c}\text { Tingkat } \\
\text { Validasi }\end{array}$ \\
\hline 1. & RPP & 3.61 & Valid \\
\hline 2. & LKPD & 3.63 & Valid \\
\hline 3. & Modul & 3.67 & Valid \\
\hline 4. & Tes Awal Kemampuan Berpikir Kritis Matematis & 3.85 & Valid \\
\hline 5. & Tes Akhir Kemampuan Berpikir Kritis Matematis & 3.81 & Valid \\
\hline
\end{tabular}

Berdasarkan Tabel 1. didapat bahwa rata-rata total validitas perangkat pembelajaran berada pada interval: $3 \leq V a<4$. Berdasarkan kriteria kevalidan maka dapat dikatakan bahwa perangkat pembelajaran yang dikembangkan "Valid".

Analisis selanjutnya berdasarkan respon para ahli/validator dan praktisi (guru) menyatakan bahwa secara perangkat pembelajaran berbasis penemuan terbimbing menggunakan hypercontent dapat digunakan dengan revisi sesuai saran. Respon ini diberikan pada para ahli/validator dan praktisi (guru) sekaligus dengan pemberian lembar validasi perangkat. Sehingga, kesimpulannya kriteria kepraktisan pertama telah dipenuhi yaitu dapat digunakan dengan revisi sesuai saran. Hasil penilaian ahli dan praktisi atas kepraktisan perangkat pembelajaran berbasis penemuan terbimbing dapat dilihat pada Tabel 2. berikut:

Tabel 2. Rekomendasi Validator atas Penggunaan Perangkat Pembelajaran

\begin{tabular}{|l|c|c|c|c|}
\hline Validator & $\begin{array}{c}\text { Perangkat } \\
\text { Pembelajaran }\end{array}$ & Validator & $\begin{array}{c}\text { Perangkat } \\
\text { Pembelajaran }\end{array}$ & Validator \\
\hline & RPP & & RPP & \\
\hline Validator 1 & SR & Validator 1 & SR & Validator 1 \\
\hline Validator 2 & SR & Validator 2 & SR & Validator 2 \\
\hline Validator 3 & TR & Validator 3 & TR & Validator 3 \\
\hline Validator 4 & TR & Validator 4 & TR & Validator 4 \\
\hline Validator 5 & TR & Validator 5 & TR & Validator 5 \\
\hline
\end{tabular}

Keterangan:

SR : Perangkat pembelajaran dapat digunakan dengan "sedikit revisi"

TR : Perangkat pembelajaran dapat digunakan dengan "tanpa revisi"

Pada Tabel 2. dapat dilihat bahwa ahli dan praktisi menyatakan bahwa perangkat pembelajaran berbasis penemuan terbimbing menggunakan hypercontent dapat digunakan dengan sedikit revisi. Jadi, sesuai dengan kriteria kepraktisan, maka perangkat pembelajaran telah memenuhi kriteria praktis menurut ahli. 


\section{Hasil uji coba I}

Tes kemampuan berpikir kritis matematis dilakukan satu kali diawal sebelum kegiatan pembelajaran dimulai yang disebut dengan Pre-Test dan satu kali diakhir pembelajaran setelah melaksanakan tiga kali pertemuan kegiatan belajar mengajar yang disebut dengan Post-Test. Pemberian Pre-Test dan Post-Test bertujuan untuk mengetahui peningkatan kemampuan berpikir kritis matematis yang diperoleh siswa setelah diberi perlakuan pembelajaran berbasis penemuan terbimbing pada materi barisan dan deret. Adapun data hasil uji coba I dapat dilihat pada Tabel 3. berikut:

Tabel 3. Hasil Tes Kemampuan Berpikir Kritis Matematis Uji Coba I

\begin{tabular}{|l|l|l|l|l|}
\hline \multirow{2}{*}{ Kategori } & \multicolumn{1}{|c|}{ Pretest } & Presentase & Posttest & Presentase \\
\cline { 2 - 2 } & $\begin{array}{c}\text { Jumlah } \\
\text { siswa }\end{array}$ & $\begin{array}{c}\text { ketuntasan } \\
\text { klasikal }\end{array}$ & $\begin{array}{c}\text { Jumlah } \\
\text { siswa }\end{array}$ & $\begin{array}{c}\text { ketuntasan } \\
\text { klasikal }\end{array}$ \\
\hline Tuntas & 4 & $15,4 \%$ & 12 & $46,1 \%$ \\
\hline Tidak Tuntas & 22 & $84,6 \%$ & 14 & $53,9 \%$ \\
\hline Jumlah & 26 & $100 \%$ & 26 & $100 \%$ \\
\hline Rata-rata Kelas & $\mathbf{5 7 , 1 4}$ & & $\mathbf{7 0 , 8 8}$ & \\
\hline
\end{tabular}

Hasil tes kemampuan berpikir kritis matematis setiap aspek ditampilkan seperti pada Tabel 4. berikut:

Tabel 4. Hasil Tes Kemampuan Berpikir Kritis Matematis Setiap Aspek pada Uji Coba I

\begin{tabular}{|l|l|l|}
\hline \multirow{2}{*}{ Aspek Berpikir Kritis Matematis } & \multicolumn{2}{|l|}{ Rata-rata (Mean) } \\
\cline { 2 - 3 } & Pretest & Postest \\
\hline Interpretasi & 13,04 & 16,42 \\
\hline Analisis & 11,38 & 11,62 \\
\hline Evaluasi & 13,46 & 18,58 \\
\hline Inferensi & 2,11 & 3 \\
\hline Keseluruhan aspek & $\mathbf{3 9 , 9 9}$ & $\mathbf{4 9 , 6 2}$ \\
\hline
\end{tabular}

Berdasarkan Tabel 4. dapat dilihat bahwa rata-rata nilai pada setiap aspek mengalami peningkatan, peningkatan tertinggi adalah 5,12 yakni aspek Evaluasi. Sedangkan peningkatan terendah adalah aspek analisis yaitu 0,24 .

\section{Hasil uji coba II}

Tes kemampuan berpikir kritis matematis dilakukan satu kali diawal sebelum kegiatan pembelajaran dimulai yang disebut dengan Pre-Test dan satu kali diakhir pembelajaran setelah melaksanakan tiga kali pertemuan kegiatan belajar mengajar yang disebut dengan Post-Test. Pemberian Pre-Test dan Post-Test bertujuan untuk mengetahui peningkatan kemampuan berpikir kritis matematis yang diperoleh siswa setelah diberi perlakuan pembelajaran berbasis penemuan terbimbing pada materi barisan dan deret. Adapun data hasil uji coba II dapat dilihat pada Tabel 5. berikut: 
Pengembangan Perangkat Pembelajaran Berbasis Penemuan Terbimbing Menggunakan Hypercontent untuk Meningkatkan Kemampuan Berpikir Kritis Matematis Siswa, Maulidia Wanahari ${ }^{1}$, Zul Amry ${ }^{2}$, Elmanani Simamora 677

Tabel 5. Hasil Tes Kemampuan Berpikir Kritis Matematis Uji Coba II

\begin{tabular}{|c|c|c|c|c|}
\hline \multirow[b]{2}{*}{ Kategori } & Pretest & \multirow{2}{*}{$\begin{array}{c}\text { Presentase } \\
\text { ketuntasan } \\
\text { klasikal }\end{array}$} & Posttest & \multirow{2}{*}{$\begin{array}{c}\text { Presentase } \\
\text { ketuntasan } \\
\text { klasikal }\end{array}$} \\
\hline & $\begin{array}{c}\text { Jumlah } \\
\text { siswa }\end{array}$ & & $\begin{array}{c}\text { Jumlah } \\
\text { siswa }\end{array}$ & \\
\hline Tuntas & 12 & $46,1 \%$ & 23 & $88,4 \%$ \\
\hline Tidak Tuntas & 14 & $53,9 \%$ & 3 & $11,6 \%$ \\
\hline Jumlah & 26 & $100 \%$ & 26 & $100 \%$ \\
\hline Rata-rata Kelas & 68 & & 79,2 & \\
\hline
\end{tabular}

Hasil tes kemampuan berpikir kritis matematis setiap aspek ditampilkan pada Tabel 6. sebagai berikut:

Tabel 6. Hasil Tes Kemampuan Berpikir Kritis Matematis Setiap Aspek pada Uji Coba II

\begin{tabular}{|l|l|l|}
\hline \multirow{2}{*}{ Aspek Berpikir Kritis Matematis } & \multicolumn{2}{|c|}{ Rata-rata (Mean) } \\
\cline { 2 - 3 } & \multicolumn{1}{|c|}{ Pretes } & \multicolumn{1}{c|}{ Postes } \\
\hline Interpretasi & 15,27 & 17,31 \\
\hline Analisis & 11,65 & 13,65 \\
\hline Evaluasi & 17,42 & 19,46 \\
\hline Inferensi & 3,27 & 5 \\
\hline Keseluruhan aspek & 47,61 & 55,42 \\
\hline
\end{tabular}

Dari Tabel 6. dapat dilihat bahwa rata-rata nilai pada setiap aspek mengalami peningkatan, peningkatan tertinggi adalah 2,04 yakni aspek Interpretasi dan Evaluasi. Sedangkan peningkatan terendah adalah Inferensi yaitu 1,73 .

\section{Pengujian hipotesis}

Analisis yang digunakan adalah uji-t dengan bantuan SPSS 22. Uji-t kemampuan berpikir kritis matematis bertujuan untuk mengetahui apakah rata-rata nilai peningkatan kemampuan berpikir kritis matematis siswa yang diberi pembelajaran dengan menggunakan perangkat pembelajaran berbasis penemuan terbimbing menggunakan hypercontent pada uji coba 2 lebih tinggi dari pada ratarata nilai peningkatan kemampuan berpikir kritis matematis siswa yang diberi pembelajaran dengan menggunakan perangkat pembelajaran berbasis penemuan terbimbing menggunakan hypercontent pada uji coba 1 di SMAN 1 Tambangan.

Adapun ringkasan uji t rata-rata nilai peningkatan kemampuan berpikir kritis matematis siswa yang diberi pembelajaran dengan menggunakan perangkat pembelajaran berbasis penemuan terbimbing menggunakan hypercontent pada uji coba 1 dengan rata-rata nilai peningkatan kemampuan berpikir kritis matematis siswa yang diberi pembelajaran dengan menggunakan perangkat pembelajaran berbasis penemuan terbimbing menggunakan hypercontent pada uji coba 2 ditunjukan pada Tabel 7. berikut:

Tabel 7. Ringkasan Hasil Uji t Kemampuan Berpikir Kritis Matematis

\begin{tabular}{|l|l|l|c|c|}
\hline & Rata-rata & $\mathbf{t}_{\text {hitung }}$ & $\mathbf{t}_{\text {tabel }}$ & P \\
\hline Uji Coba 1 & 70,46 & 4,436 & 2,060 & 0.000 \\
\cline { 1 - 2 } Uji Coba 2 & 78,73 & & & \\
\hline
\end{tabular}


Berdasarkan Tabel 7. didapatkan bahwa rata-rata nilai peningkatan kemampuan berpikir kritis matematis siswa yang diberi pembelajaran dengan menggunakan perangkat pembelajaran berbasis penemuan terbimbing menggunakan hypercontent pada uji coba 1 sebesar 70,46 dan rata-rata nilai peningkatan kemampuan berpikir kritis matematis siswa yang diberi pembelajaran dengan menggunakan perangkat pembelajaran berbasis penemuan terbimbing menggunakan hypercontent pada uji coba 2 sebesar 78,73 sehingga terdapat perbedaan sebesar 8,27. Didapatkan juga thitung $>\mathrm{t}$ tabel pada taraf signifikansi $5 \%(4,436>2,060)$ dan mempunyai nilai $\mathrm{p}<0,05$ yang berarti H0 ditolak sehingga dapat disimpulkan bahwa rata-rata nilai peningkatan kemampuan berpikir kritis matematis siswa yang diberi pembelajaran dengan menggunakan perangkat pembelajaran berbasis penemuan terbimbing menggunakan hypercontent pada uji coba 2 lebih tinggi dari pada uji coba 1 di SMAN 1 Tambangan sehingga perbedaan tersebut dinyatakan signifikan.

\section{Tahap Penyebaran (Disseminate)}

Langkah selanjutnya adalah dilakukannya penyebaran terbatas berupa penyebaran perangkat final kepada forum MGMP di SMAN 1 Tambangan yang ditandai dengan penyerahan perangkat pembelajaran kepada forum MGMP dengan harapan guru matematika yang tergabung dalam forum tersebut dapat menerapkan perangkat pembalajaran tersebut pada pembelajaran selanjutnya.

\section{Diskusi}

\section{Pengembangan perangkat pembelajaran}

Komponen perangkat pembelajaran yang dikembangkan dengan menggunakan berbasis penemuan terbimbing menggunakan hypercontent berada pada kategori "valid" dengan nilai rata-rata masing-masing komponen yaitu 3,61; 3,63; 3,67; 3,85 dan 43,81. Tetapi walaupun komponen perangkat pembelajaran yang dikembangkan telah memenuhi kriteria kevalidan, ada beberapa hal yang harus diperbaiki sesuai dengan catatan-catatan yang diberikan oleh tim ahli meliputi penggunaan bahasa, penulisan atau pengetikan dan tampilan gambar yang harus sesuai dengan kondisi diperjelas. Sehingga berdasarkan hasil catatan dari para tim ahli bahwa perangkat pembelajaran ini telah memenuhi kriteria kevalidan dengan kategori "valid" dengan catatan sedikit revisi.

Pemenuhan aspek validitas sejalan dengan pendapat Akker (van den Akker, 1999) yang menyatakan bahwa validitas mengacu pada sejauh desain dari perangkat didasarkan pada keadaan terbaru dari teknologi, seni atau ilmu ('validitas isi') dan berbagai variasi komponen dari perangkat secara konsisten berkaitan satu sama lain ('validitas konstruk').

Selain validitas, diperlukan juga kepraktisan sebagai syarat perangkat pembelajaran yang baik. Dalam penelitian ini ditetapkan 2 indikator kepraktisan yaitu respon tim ahli atau validator yang menyatakan bahwa perangkat pembelajaran dapat digunakan dengan revisi kecil dan keterlaksanaan perangkat pembelajaran berbasis penemuan terbimbing menggunakan hypercontent berada pada kriteria $I O=4,44$ tinggi.

Selain kepraktisan, diperlukan juga efektivitas sebagai syarat perangkat pembelajaran yang baik. Dalam penelitian ini ditetapkan 3 indikator efektivitas, yaitu ketercapaian ketuntasan belajar 
Pengembangan Perangkat Pembelajaran Berbasis Penemuan Terbimbing Menggunakan Hypercontent untuk Meningkatkan Kemampuan Berpikir Kritis Matematis Siswa, Maulidia Wanahari ${ }^{1}$, Zul Amry ${ }^{2}$, Elmanani Simamora 679

siswa, kemampuan guru dalam mengelola pembelajaran diperoleh rata-rata 4,08 atau dalam kategori "baik" dan Respon siswa terhadap pembelajaran diperoleh rata-rata 90,38\%

Dari hasil respon tim ahli dan kemampuan guru dalam mengelola pembelajaran, dapat disimpulkan bahwa perangkat pembelajaran berbasis penemuan terbimbing menggunakan hypercontent "praktis" untuk digunakan di dalam pembelajaran.

Hasil tersebut sejalan dengan penelitian Ihsan Fuadi (Fuadi, 2017) menunjukkan bahwa perangkat pembelajaran berbasis model penemuan terbimbing ini telah valid, praktis, dan efektif yang memiliki karakteristik sebagai berikut. (1) Perangkat Pembelajaran yang meliputi rencana pelaksanaan pembelajaran, lembar kegiatan siswa, buku siswa memenuhi kriteria kevalidan berdasarkan para ahli sedangkan instrumen berupa tes kemampuan pemecahan masalah matematik siswa memenuhi kriteria kevalidan berdasarkan para ahli dan tes validitas dan reliabilitas, (2) Perangkat pembelajaran yang meliputi rencana pelaksanaan pembelajaran, lembar kegiatan siswa, dan buku siswa praktis untuk digunakan, dan (3) Perangkat pembelajaran yang meliputi rencana pelaksanaan pembelajaran, lembar kegiatan siswa, buku siswa, dan tes kemampuan pemecahan masalah matematik siswa telah memenuhi kriteria keefektifan pada uji coba I, sedangkan kemampuan pemecahan masalah matematik siswa mengalami peningkatan pada uji coba II.

\section{Kemampuan Berpikir Kritis Matematis}

Dari hasil uji coba I dan uji coba II diperoleh hasil $N$-Gain tes kemampuan berpikir kritis matematis siswa terlihat pada Tabel 8. berikut:

Tabel 8. Hasil N-Gain Kemampuan Berpikir Kritis Matematis Uji Coba I dan Uji Coba II

\begin{tabular}{|c|l|c|c|}
\hline \multirow{2}{*}{ No } & \multirow{2}{*}{ Indikator } & \multicolumn{2}{|c|}{ N-Gain } \\
\cline { 3 - 4 } & & Uji Coba I & Uji Coba II \\
\hline 1 & Interpretasi & 0,5 & 0,4 \\
\hline 2 & Analisis & 0,03 & 0,2 \\
\hline 3 & Evaluasi & 0,8 & 0,8 \\
\hline 4 & Inferensi & 0,1 & 0,3 \\
\hline
\end{tabular}

Berdasarkan tabel 8, terlihat nilai $N$-Gain perindikator berpikir kritis matematis pada Uji Coba I masing-masing adalah 0,$5 ; 0,03$ dan 0,8 dan 0,1 . Sedangkan pada Uji Coba II masing-masing adalah 0,$4 ; 0,2 ; 0,8$ dan 0,3 . Sehingga indikator yang paling tinggi peningkatannya adalah indikator ketiga pada Uji Coba I dan II dengan nilai $N$-gain 0,8 yakni Evaluasi.

\section{KESIMPULAN}

Perangkat pembelajaran berbasis penemuan terbimbing menggunakan hypercontent untuk meningkatkan kemampuan berpikir kritis matematis siswa yang dikembangkan sudah memenuhi kriteria valid, praktis dan efektif yakni:

1. Kevalidan dengan rata-rata validitas RPP sebesar 3,61, rata-rata validitas lembar kerja peserta didik sebesar 3,63, rata-rata validitas modul 3,67. 
2. Kepraktisan ditinjau dari 1) Respon tim ahli atau validator yang menyatakan bahwa perangkat pembelajaran dapat digunakan dengan revisi kecil 2) Keterlaksanaan perangkat pembelajaran pada kriteria $I O=4,44$ tinggi.

3. Keefektifan ditinjau dari 1) Ketuntasan klasikal mencapai $88,4 \%$ yakni telah memenuhi kriteria ketuntasan yakni $\geq 85 \%$ siswa mencapai KKM. 2) Kemampuan guru dalam mengelola pembelajaran diperoleh rata-rata 4,08 atau dalam kategori "baik". 3) Respon siswa terhadap pembelajaran diperoleh rata-rata $90,38 \%$.

4. Peningkatan kemampuan berpikir kritis matematis menggunakan perangkat pembelajaran berbasis penemuan terbimbing menggunakan hypercontent yang telah dikembangkan dilihat dari nilai $\mathrm{N}$ gain pada uji coba I sebesar 0,33 meningkat menjadi 0,4 pada uji coba II, artinya berada dalam kategori "sedang".

\section{UCAPAN TERIMA KASIH}

Terima kasih saya ucapkan kepada dosen pembimbing Bapak Prof. Drs. Zul Amry, M.Si., Ph.D. dan bapak Dr. Elmanani Simamora, M.Si. Terimakasih juga saya ucapkan untuk semua pihak yang membantu dalam menyelesaikan penelitian ini.

\section{REFERENSI}

Van den Akker, Jan. 1999. "Principles and Methods of Development Research." Design Approaches and Tools in Education and Training: 1-14.

Fuadi, Ihsan. 2017. "Pengembangan Perangkat Pembelajaran Berbasis Model Penemuan Terbimbing Untuk Meningkatkan Kemampuan Pemecahan Masalah Matematik Siswa SMA Negeri 8 Medan." universitas negeri medan.

Lestari, K.E dan Yudhanegara, M.R. 2017. Penelitian Pendidikan Matematika (Panduan Praktis Menyusun Skripsi, Tesis, Dan Laporan Penelitian Dengan Pendekatan Kuantitatif, Kualitatif, Dan Kombinasi Disertai Dengan Model Pembelajaran Dan Kemampuan Matematis). bandung.

Mardati, Asih. 2018. "Pendekatan Penemuan Terbimbing Dalam Pembelajaran Matematika Untuk Menghadapi Tantangan Abad 21." Universitas Ahma Dahlan: 4-5.

Prawiradilaga, D. S., \& Chaeruman, U. A. 2018. Modul Hypercontent: Teknologi Kinerja (Performance Technology). pertama. https://books.google.co.id/books? id=lN-2DwAAQBAJ.

Prawiradilaga, Dewi Salma, Retno Widyaningrum, and Diana Ariani. 2017. "Prinsip-Prinsip Dasar Pengembangan Modul Berpendekatan Hypercontent." Indonesian Journal of Curriculum and Educational Technology Studies 5(2): 57-65.

Siahaan, Meri Fuji. 2017. "Students' Perceptions of the Constructivist Instructional Methods in a Teaching and Learning Course." IJPTE: International Journal of Pedagogy and Teacher Education 1(2): 155-73.

Siang, Jhoni Lagun, Nurdin Ibrahim, and Rusmono. 2017. "Pengembangan Paket Modul Cetak Mata Pelajaran Pendidikan Agama Kristen SMP Negeri Tidore Kepulauan.” Jurnal Teknologi Pendidikan 19(3): 191-205.

Sugiyono. 2012. Metode Penelitian Kuantitatif, Kualitatif Dan R\&D. pertama. bandung: alfabeta. 
Pengembangan Perangkat Pembelajaran Berbasis Penemuan Terbimbing Menggunakan Hypercontent untuk Meningkatkan Kemampuan Berpikir Kritis Matematis Siswa, Maulidia Wanahari ${ }^{1}$, Zul Amry ${ }^{2}$, Elmanani Simamora 681

https://cvalfabeta.com/product/metode-penelitian-kuantitatif-kualitatif-dan-rd-mpkk/.

Wena, Made. 2009. Strategi Pembelajaran Inovetif Kontemporer: Suatu Tinjauan Konseptual Operasional. jakarta: bumi aksara.

Yohanis, J., Triwiyono, Modouw, W. 2013. "Pengembangan Modul Pembelajaran Fisika Bilingual Kelas X Pokok Bahasan Gerak Lurus Di SMA Negeri 3 Jayapura." urnal Ilmu Pendidikan Indonesia. I: 10-19. https://garuda.kemdikbud.go.id/author/view/575956. 